Article

\title{
Exploring the Place of Animals and Human-Animal Relationships in Hydraulic Fracturing Discourse
}

\author{
Cameron T. Whitley
}

Faculty of Arts and Sciences, Rutgers University, Camden, NJ 08102, USA; cameron.whitley@rutgers.edu

Received: 23 January 2019; Accepted: 11 February 2019; Published: 18 February 2019

check for updates

\begin{abstract}
Throughout human history, energy security has been a prominent concern. Historically, animals were used as energy providers and as companions and sentinels in mining operations. While animals are seldom used for these purposes in developed communities today, this legacy of use is likely to have far-reaching consequences for how animals and human-animal relationships are acknowledged in energy development. The US is currently experiencing an energy boom in the form of high volume horizontal drilling and hydraulic fracturing (HVHHF); because animals are the most at risk from this boom, this study uses a thorough content analysis of peer-reviewed HVHHF articles mentioning animals from 2012-2018 to assess how animals and human-animal relationships are discussed. Three dominant article theme classifications emerge: animal-focused articles, animal-observant articles, and animal sentinel articles. Across themes, articles seldom acknowledge the inherent value or the social and psychological importance of animals in human lives; instead, the focus is almost exclusively on the use of animals as sentinels for potential human health risks. Further, what is nearly absent from this body of literature is any social science research. Given that relationships with animals are an integral part of human existence, this study applies environmental justice principles, serving as a call to action for social science scholars to address the impacts of HVHHF on animals and human-animal relationships.
\end{abstract}

Keywords: hydraulic fracturing; animal studies; environmental sociology; environmental justice; companion animals; energy development

\section{Introduction}

On a small plot of land in Pennsylvania, Stacey Haney and Beth Voyles raised animals and children. In 2008, they combined their land in order to rent it to a Texas-based oil company that would use high volume horizontal drilling and hydraulic fracturing (HVHHF) to harvest natural gas. Both women thought it was a beneficial plan, providing them with additional income for their respective farms. However, in less than a year after drilling began, Haney's animals, Hunter (dog), Boots (goat), and Boots' offspring had all died. Similarly, Voyles lost her prized dog, Cummins, and at least 15 of Cummins' offspring. Both families also experienced health repercussions (see, e.g., (Griswold 2011)). Their land sits above the Marcellus Shale Deposit, which is an American natural-gas field often used for HVHHF. HVHHF is a type of energy development that involves forcing high volumes of water, sand, and hundreds of hazardous chemicals into horizontally drilled wells to stimulate fractures and free up oil and gas stores that can then be recovered.

Over the last two decades, there has been increased debate and documentation of the impacts that HVHHF is having, and will have, on communities and individuals. Social scientists have been at the forefront of this discussion, detailing such things as the public perceptions of the social-environmental issues caused by HVHHF (Ladd 2013, 2018; Morrone et al. 2015; Vasi et al. 2015), local opposition and community division over HVHHF, differences in public and elite perceptions (Crowe et al. 2015), influence of familiarity with HVHHF on opinion (Willits et al. 2016), and HVHHF's negative impacts 
(Hauter 2016). What this literature tells us is that there is great division among the general public about the necessity of HVHHF and the impacts that it will have on individuals and communities. More importantly, the nuances in energy development discussions and perceptions are often location or community specific (see, e.g., Hula et al. 2017). Although, as the text above details, animals are an integral part of the HVHHF story, little attention has been paid to addressing the intersection of humans, animals, and HVHHF.

Outside of energy debates, social scientists are increasingly recognizing the value of including animals and human-animal relationships in social research, often discussing animals as a critically important but missing or overlooked variable (Carter and Charles 2018; Cudworth 2015; Peggs 2012; Tovey 2003). By bringing animals back into the conversation, social scientists have identified important connections that have led to significant social and policy changes. For instance, Fitzgerald and colleagues (Barrett et al. 2018; Fitzgerald 2007) argue that women in abusive relationships are often reluctant to leave their abusive partners because of fear that their companion animals may sustain increased violence or that domestic violence shelters will not accept them with a companion animal. This finding has led to an increase in domestic violence shelters accepting companion animals. In another area of research, Irvine (2009) documents the horrors of animal violence, neglect and abuse by authorities that kept local residents from leaving their homes during hurricane Katrina. This extended conversation led to the 2006 federal Pets Evacuation and Transportation Standards (PETS) Act, which directs state and local emergency plans to take pets and service animals into account in emergency planning. While these are only two examples of many, they demonstrate how understanding animals and human-animal relationships is becoming critical to understanding larger social issues. The current article is designed to continue this conversation, by looking at how animals (wild, agriculture and companion) and human-animal relationships are discussed and addressed in HVHHF research.

In 2012, Michelle Bamberger and Robert Oswald, a veterinarian and a pharmacologist, published a paper with the intention of starting a conversation about the impacts of HVHHF on animal populations and the associated connections to human health. Their article relies on 24 reported cases of animal harm. Opening a new avenue for discussion and making clear connections between animal and human well-being, the paper received widespread attention (see, e.g., Phillips 2012). Although their paper does not offer generalizable statements about the broad impacts of HVHHF on animals or the associated costs to human health, it does raise numerous questions about the use of animals as, what Whitley (2017) terms, unintentional sentinels in the expansion of HVHHF. This issue should be part of a larger discussion about the use of animals in energy development, a topic that has implications for both animal and human health, as well as for human-animal relationships more broadly.

Animals have a long and varied history in energy development that has often been overlooked (see, e.g., Whitley 2017, 2018). From antiquity until recent times, animals were used as energy providers. This dynamic only changed with technological innovation, at which point animals became intentional sentinels in mining operations and laboratory experiments, being used to assess the risks that mining toxins posed to humans. Though using animals as intentional sentinels fell out of favor in the 1960s, HVHHF's rapid expansion has reintroduced their use as harbingers of human risk. Researchers are monitoring (as unintentional sentinels) and once again conducting laboratory experiments on animals (as intentional sentinels) to assess the impacts of HVHHF toxin exposure, often with the objective of learning more about potential risks to human health.

Understanding the impact HVHHF has on animals and human-animal relationships is important for four key reasons. First, animals are inherently valuable; they contribute to ecosystem success and HVHHF will likely have individual and symbiotic impacts on their wellbeing. Second, although impacts on animals may signal potential risks to humans, they are also likely to impact human-animal relationships. For instance, in the example above, Haney and Voyles both experienced psychological trauma over the loss of their animals. Such trauma could be magnified in sensitive populations such as in senior populations living with pets (see, e.g., Himsworth and Rock 2013). In addition, this type 
of trauma could have implications for animal ownership and rescue in high HVHHF regions. Third, the impact HVHHF has on animals may affect public perceptions of risk and behavior, as is the case with natural disasters, where harm to animals influences individuals' risk perceptions and behaviors (see, e.g., Irvine 2009). Additionally, HVHHF can impact veterinary services. Bamberger and Oswald (2012) argue that non-disclosure policies make treating animals exposed to HVHHF fluids a challenge. Along these lines, veterinarians in high HVHHF areas are likely coming into contact with greater numbers of exposure cases, changing how veterinary medicine is practiced.

Research on HVHHF is highly interdisciplinary and implications for animals are often embedded in ways that make it unclear whether these topics are being investigated. This study seeks to overcome this challenge by conducting a thorough content analysis of all peer-reviewed literature, published from 2012-2018, on HVHHF that mentions animals to provide a report on the state of the field that (1) determines how animals and human-animal relationships are featured in scientific literature on the impacts of HVHHF; (2) identifies themes among the suite of studies and; (3) assesses what additional research is needed as a call to action.

\section{Background and Theory}

\section{Environmental Justice and the Place of Animals}

The recognition of animals in energy development and the associated link to human lives is best situated within an environmental justice (EJ) framework. Historically, EJ has addressed the inequitable distribution of environmental services and burdens to vulnerable populations. Social scientists have long drawn on work from deviance studies, political economy and environmental justice to explain toxic exposure, consistently concluding that the poor and people of color have been victims of egregious ecological injustice (see, e.g., Mohai and Saha 2006, 2007). This literature is connected to a larger body of work that assesses how social and political inequalities are reinforced through access and distribution of the natural environment (see, e.g., Bullard 2005; Pellow 2017). Much of the literature is focused on the production, manipulation and unlawful disposal of toxic waste (see, e.g., Massari and Monzini 2004; Pearce and Tombs 2009; Ruggiero 1996). It should be noted that this body of literature within social science originated with a human emphasis. Specifically, Bullard and colleagues (Bullard 1994; Bullard and Wright 1993) were attempting to counter the environmental movement approach, which focused on impacts on the natural environment, by drawing attention to the impacts on vulnerable populations. At this time, the recognition of the interconnectedness between humans and animals was not fully realized, and remains an issue. EJ scholar David Pellow has been particularly interested in reincorporating animals into EJ conversations, especially around toxic exposure (Mohai et al. 2009; Pellow 2014, 2017). However, there remains a space for a deeper discussion not just about the impacts on wildlife populations, but about the shared impacts across species and the impact on human-animal relationships broadly.

Though there has been a concerted effort to apply concepts of EJ to human populations, nonhuman animals remain nearly absent from this discourse (Kopnina 2014). Kopnina (2014) argues that scholars are influenced by the "dominant neoliberal ideology of anthropocentrism" (p. 2) (see also, e.g., Callicott 1999; Catton and Dunlap 1978; Crist 2012; Kopnina 2012a, 2012b). The traditional tendency of social science to be anthropocentric has limited inquiry into animal-environment issues to discussions of the implications of these issues to humans, without regard for the inherent value of animal species (Beirne 2009; Nibert 2002). Kopnina (2014) clarifies this argument, suggesting that the "view of animals as culturally, socially or economically significant objects sees non-humans as facilitators of technological advancements (e.g., medical experiments or genetic manipulations), as an attribute of cultural practice (hunting or whaling) as the objects of economic interest (e.g., animal trade) symbolic ritual (e.g., animal sacrifice), or collateral damage (e.g., road kill or forest clearings)" (p. 4). In energy development, animals have not only been the facilitators of technological advancements, but they have 
also served as sentinels, living indicators of risks posed to humans (Whitley 2017). In this way, the use and investigation of animals in energy development has been and remains anthropocentric.

An issue becomes an EJ concern when it is socially constructed as a problem (Taylor 2000). White (2013) argues that the nature of mining inherently creates EJ concerns because vulnerable populations always suffer. Several researchers have documented the potential risks HVHHF poses to human health through water contamination, fracking fluid spills, air pollution, etc. (Korfmacher et al. 2013; Kovats et al. 2014; Wattenberg et al. 2015). In doing so, these researchers have constructed a narrative about HVHHF as an EJ issue, with a focus on human health implications. What remains absent from this work, and the larger body of EJ literature, is any recognition of animals or human-animal relationships.

Schlosberg (2013) argues that, "one of the remaining border challenges of environmental justice theory is to make important connections with the environment itself ... Yes, most of the discussion is about environmental bads and injustices to human beings, but the origins of environmental injustices are as much in the treatment of the non-human realm as in relations among human beings" (pp. 43-44). Although all mining practices have environmental impacts, the expansion of development, potential for chemical pollution, and hydrological alteration make HVHHF particularly concerning. Animals are likely to be the first affected in HVHHF development. Direct impacts on animals could have lasting effects on biodiversity and ecological services (Kiviat 2013). In particular, vulnerable animal populations such as those who have restricted ranges, are sensitive to environmental changes, or if endangered, may experience amplified effects. The potential risks are so concerning that HVHHF has been identified as a global conservation issue (Lloyd et al. 2005). Importantly, wildlife are not the only victims; the health and wellbeing of livestock and companion animals is also at risk (see, e.g., Bamberger and Oswald 2012, 2015), bringing up questions about the rights of animals to have equitable access to environmental services such as clean water and air. This study seeks to demonstrate that HVHHF is not just an EJ issue for humans, but that animals and human-animal relationships should be considered as well. The study that follows uses a content analysis approach to evaluate the extent to which animals are considered in HVHHF discussions within peer reviewed journal articles. In doing so, it provides tangible evidence in support of Schlosberg (2013) assertion that we need more discussions of animals as victims in environmental justice narratives.

\section{Data}

All peer-reviewed articles published between 2012 and 2018 that are about HVHHF and mention animals were examined. To ensure that the analysis is inclusive, data collection was conducted using three steps. The process began with Bamberger and Oswald's 2012 paper, described in the introduction, as it is considered the seminal article exploring the potential impacts HVHHF has on animals. All citations within the articles citing Bamberger and Oswald (2012) were analyzed. Next, all peer-reviewed articles citing Bamberger and Oswald (2012) were reviewed. Finally, the resulting list was cross-referenced with a search in the Web of Science database looking for peer-reviewed articles featuring hydraulic fracturing (using key terms: hydraulic fracturing, fracking, unconventional energy development, and natural gas development) and animals (using key terms: animals, ecosystems, fisheries, wildlife, livestock, agriculture, invertebrates, biodiversity, fauna, and mammals). A total of 118 articles were identified.

\section{Method}

A content analysis approach was applied, which is a widely used technique to identify and describe patterns in textual data. All text was coded in Nvivo 11.4. Nvivo is a qualitative data analysis software tool that allows for the coding, sorting, querying and sharing of unstructured data. Line data were coded into nodes and then consolidated into categorical themes. First, all articles were reviewed to give the researcher a feel for these data. Second, abstracts were coded for the presence of animal terms. For instance, if animals were featured in the abstract it was assumed that the animals were 
a central focus of the article. If animals were not featured in the abstract, it was assumed that they had little importance in the article or were simply a line reference. Additional nodes were identified to code the central themes of each abstract, regardless of animal inclusion. Abstracts were chosen as the first level of analysis, because they provide summaries of articles and are likely the first thing people assess before reading an entire article. Third, a line-by-line review of all articles was done to assess when and how animals were discussed. Finally, a second coder was asked to independently code all text. Inconsistencies between the two coders were discussed until consensus was reached. Limited inconsistencies were found, as nodes relied on the presence of specific words related to animals or other subcategories of environmental and social impacts. Three major themes emerged. These themes and the associated subthemes are discussed below.

\section{Results and Discussion}

The analysis aims to clarify how animals and human-animal relationships are included or excluded in scientific discussion on HVHHF. Of the 118 articles analyzed, only 44 (37\%) mention animals in the abstract. Across all articles, three dominant themes emerged. First, 25 (21\%) articles directly mention animals or ecosystems in the abstract and focus on the impacts HVHHF has on a specific animal, group, or species. These 25 articles are referred to as "animal-focused" articles. Second, $23(20 \%)$ articles review the impacts of HVHHF and mention animals or ecosystems in the abstract but do not exclusively focus on animals, including non-animal impacts as well. These are referred to as "animal-observant" articles. Finally, the majority of articles (70 articles, 59\%) did not mention animals in the abstract but cited the Bamberger and Oswald (2012) article to support a claim about the impacts of HVHHF on humans. These articles are referred to as "animal-sentinel" articles. Within each theme, subthemes emerged.

\subsection{Animal-Focused Articles}

The articles within this group either provide a general overview of the impacts of HVHHF on ecosystems or focus on specific impacts on a species. General overviews of ecosystem impacts consistently conclude that freshwater organisms, species sensitive to land fragmentation, and animals with restricted ranges are the most at risk (Gillen and Kiviat 2012; Kiviat 2013). In these articles, animals are the focal point and the research examines how HVHHF affects them. For instance, research suggests that the redfin darter, a fish that is endangered in some US states, is vulnerable to silt input in streams (Stearman et al. 2015); native brook trout conservation and restoration are at risk (Weltman-Fahs and Taylor 2013), as are Zebra fish and their habitats (Folkerts et al. 2017; He et al. 2018); migrating fracturing fluids may cause adverse effects in rainbow trout (He et al. 2016; Folkerts et al. 2017); fish exposed to waters contaminated with fracking fluids show signs of general stress and higher incidences of gill lesions compared to unexposed fish (Papoulias and Velasco 2013); and a positive correlation exists between the presence of HVHHF wells and mercury concentrations in crayfish, and other predatory macro invertebrates and brook trout (Grant et al. 2015; Blewett et al. 2017a; Blewett et al. 2017b). In addition, non-aquatic animals may also be affected by water contamination. For instance, metal accumulation in riparian songbirds is higher in heavy HVHHF areas compared to those residing in areas without HVHHF (Latta et al. 2015) and the leopard frog may be particularly vulnerable (Funk and Stabenau 2017).

A handful of articles that focus on specific species demonstrate that land fragmentation contributes to animals avoiding roadways, which isolates them to smaller areas of land, a trend documented in grassland bird species (Thompson et al. 2015), salamanders (Brand et al. 2014), mule deer (Lendrum et al. 2012), and river otters (Godwin et al. 2015). Although land fragmentation is not likely to have a big impact on livestock and companion animals, range restrictions might; despite this possibility, studies of the impacts of HVHHF on livestock and companion animals are scarce. For instance, in the only identified study on livestock, Finkel et al. (2013b) assess how HVHHF affects cow and milk production over a five-year period, finding that production decreased as 
HVHHF development increased. Similarly, beyond the original Bamberger and Oswald (2012) article, only three studies report on the impacts on companion animals and human-animal relationships. First, Slizovskiy et al. (2015) use a community health survey with questions about companion and livestock health to assess how the distance to the nearest HVHHF well relates to reported human and animal health. They find that the reported health of dogs is significantly lower for people living within $1 \mathrm{~km}$ of a gas well compared to those living farther away. Second, a follow-up article by Bamberger and Oswald (2015) demonstrates that the negative health impacts decrease for families (including animals) moving away from HVHHF areas, while health impacts remain the same or increase for those continuing to reside in high volume drilling areas. Finally, in conducting interviews among Pennsylvania residents with a focus on women, McHenry (2017) finds that people are particularly concerned with how hydraulic fracturing impacts their family pets.

Assessing the articles in this thematic category leads to three broad conclusions. First, although these articles focus almost exclusively on animals and tend to argue for the inherent value of animals, they largely justify studying impacts on animals by connecting them to human systems. For example, this group of studies generally mentions human health or the preservation of ecosystem services in the conclusion as a justification for focusing exclusively or almost exclusively on animals. Second, there is limited social science research in this body of literature. Only one study, McHenry (2017), is from a social science perspective. Specifically, there is no broad assessment of how hydraulic fracturing is impacting animals or human-animal relationships; there are only assessments of the impacts on animals that may signal potential risks to humans. Finally, and perhaps most surprisingly, the lengthy history of testing mining toxins on animals to assess and mitigate human health risks is alive and well in research with a few studies reporting on the use of laboratory mice to assess toxin exposure extremes (Kassotis et al. 2015; Kassotis et al. 2016a). This is interesting because it goes beyond the assumption that animals are simply serving as unintentional sentinels in HVHHF development. Instead, this evidence suggests that animals are also serving as intentional sentinels.

\subsection{Animal-Observant Articles}

The articles in this group $(\mathrm{N}=23)$ mention animals in the context of other HVHHF risks and do not focus on a specific animal or species. In most cases, these articles focus on environmental damage or contamination. Terms such as "animals" and "ecosystems" are widely used. Unlike the previous category, the focus of these articles is on the broad effects, which happen to include impacts on animals. So, for instance, in thinking about water contamination, the author might mention all of the potential impacts, where in the previous category the analysis or discussion would be on the impacts HVHHF has on a particular species or group of animals. There are no social science articles in this group.

The majority of articles in this thematic category emphasize freshwater ecosystems as their animal focal point. This is not surprising, as these articles cite many of the "Animal-Focused Articles" listed above as supporting evidence. For instance, studies show that chemicals used in hydraulic fracturing pose a risk to ecosystems (Entrekin et al. 2018; He et al. 2017; Loh and Loh 2016; Vandecasteele et al. 2015; Yao et al. 2015). Specifically, Kassotis et al. (2016b) find that injection well disposal sites reveal elevated levels of toxins that could disrupt reproduction and development in aquatic animals (see, e.g., Elliott et al. 2017). Additionally, HVHHF leads to increases in pH in area streams (Lutz and Grant 2016), and water contamination can enter the food chain impacting cattle, poultry, and aquatic life (Kun et al. 2014; Pothukuchi et al. 2018). Notice that in all of these cases, animals are mentioned, but they are mentioned in the context of environmental contamination where the focal point is on contamination and not on animals.

Instead of centering on a particular environmental impact, some articles provide general overviews of environmental risks (Brittingham et al. 2014; Burton et al. 2014; Lave and Lutz 2014; Souther et al. 2014) or information about regulatory processes (Ralston and Kalmbach 2018). For instance, in an analysis of land use and shale development, Moran et al. (2015) assert that, "shale gas development will likely have substantial negative impact effects on forested habitats and 
the organisms that depend upon them" (p. 1276) and Abrahams et al. (2015) note, "well pads, access roads, and gathering lines fragment forestland resulting in irreversible alterations to the forest ecosystem" (p. 153). Similarly, in a paper looking at how Saskatchewan is responding to hydraulic fracturing, the authors note that people are concerned about impacts on animals and ecosystems (Olive and Valentine 2018).

Finally, a key component of articles within this theme is the effort to position research as important for supporting human systems. For example, multiple scholars argue that failing to understand threats to ecosystems and provide proper regulatory mechanisms are likely to contribute to ecosystem loss, which has implications for human health (Allred et al. 2015; Bamberger and Oswald 2014; Down et al. 2013; Finkel et al. 2013a; Finkel et al. 2013b; Jones et al. 2015; Kassotis et al. 2016a; Kassotis et al. 2016b; Robbins 2013; Ticleanu et al. 2014). Three important takeaways emerge from this group. First, articles mention animals as being impacted by HVHHF, but do not focus on a specific group or species. Second, unlike the articles in the animal-focused group, these articles center on making a connection between animal (and environmental) impacts and human health, paying less attention to the inherent value of nature or animals. Finally, there are no social science articles.

\subsection{Animal Sentinel Articles}

Animal sentinel articles do not mention animals or ecosystems in the abstract $(n=70)$. Overall, this group uses the Bamberger and Oswald (2012) article to support discussions on one of five key HVHHF subthemes: public health concerns ( $\mathrm{n}=24$ or $35 \%$ of animal sentinel articles), environmental impacts ( $n=19$ or $27 \%$ of animal sentinel articles), community impacts and public perceptions ( $n=16$ or $23 \%$ of animal sentinel articles), policy ( $n=7$ or $10 \%$ of animal sentinel articles), and general reviews of broad impacts ( $n=4$ or $6 \%$ of animal sentinel articles).

First, the largest group of articles in this theme emphasizes public health concerns ( $\mathrm{n}=$ 24). These articles discuss the impacts of HVHHF on either broad public health categories (see, e.g., Adekola et al. 2016; Boyle et al. 2016; Ferrar et al. 2013; Finkel and Hays 2013; Goldstein and Kriesky 2012; Korfmacher et al. 2013; Mitka 2012; Penning et al. 2014; Perry 2013; Rabinowitz et al. 2015; Rafferty and Limonik 2013; Redmond 2014; Saberi 2013; Saberi et al. 2014; Saunders et al. 2016; Shonkoff et al. 2014; Steinzor et al. 2013; Tuller 2015; Werner et al. 2015; Willems et al.2016) or specifically to infant or reproductive and developmental health (Kassotis et al. 2015; Ma et al. 2016; Payne et al. 2014; Webb et al. 2014). If mentioned, animals are only used to situate the potential and realized impacts on human health or to assert that more research is needed (see, e.g., Ma et al. 2016). For instance, in a review of HVHHF health impacts, Shonkoff et al. (2014) cite Bamberger and Oswald (2012) after discussing fracking fluid containment by noting "These containment ponds are often, but not always, lined to protect against leakage; however, case studies have documented reported ruptures to these liners that may have led to water and soil contamination and contributed to fish and livestock deaths (Bamberger and Oswald 2012, p. 793)". This is the only reference to animals in the article and is simply used to support the thesis that additional epidemiological studies are needed to evaluate risks to human health.

Second, a group of studies within this theme speak to environmental impacts $(n=19)$. Two articles review broad environmental impacts (Arent et al. 2015; Reible et al. 2016), while the remaining 17 focus on air quality or water use and contamination. For instance, HVHHF is known to have broad impacts on air quality (Bai et al. 2016; Brown et al. 2014; Brown et al. 2015; Bunch et al. 2014; Colborn et al. 2012; Field et al. 2014; Moore et al. 2014). Similar to the health impacts subtheme, this group minimally mentions animals in the text or uses Bamberger and Oswald (2012) as a general nod to potential impacts on human health. For instance, Bunch et al. (2014) do not mention animals at all, but cite the article to show that few "studies have focused on atmospheric emissions and, in particular, on the potential impacts of such emissions on human health" (p. 833). A second group of environmental impact articles speak to issues of water quality. For instance, these articles discuss the chemical composition of water and wastewater disposal wells near HVHHF sites (Kassotis et al. 2013; 
Rich and Crosby 2013; Zhai et al. 2016), wastewater spills and water contamination (Koh et al. 2016; Konkel 2016; Penningroth et al. 2013; Sang et al. 2014), and broad debates about water use and contamination (Ernstoff and Ellis 2013). Overall, animals are excluded or only mentioned in superficial ways.

Third, there are 16 community impacts and public perception articles. This subtheme is the only one to include social science articles. In these articles, HVHHF is evaluated in terms of public perceptions (Choma et al. 2016; Dokshin 2016; Israel et al. 2015; Morrone et al. 2015; Powers et al. 2015), community disorder and boomtown issues (Jerolmack and Berman 2016; Ruddell and Ortiz 2014), changes in traffic (Graham et al. 2015), economic impacts (Barth 2013; Muresan and Ivan 2015), broad or case-specific social impacts (Garvie et al. 2014; Perry 2012), and environmental justice and human rights (see, e.g., Clough and Bell 2016; Fry et al. 2015; Johnston et al. 2016; Short et al. 2015). Once again, these articles give little attention to the impacts of HVHHF on animals. Specifically, animals and human-animal relationships are not mentioned in survey analyses or in discussions about community impacts broadly. What is most interesting about this collection is that even among the environmental justice focused articles, animals are non-existent. For instance, in discussing the connection between human rights and HVHHF, Short et al. (2015) cite the Bamberger and Oswald (2012) article to suggest that "Land can also be impacted through water, air or soil pollution as we have seen above, along with damage to livestock, vegetation and wildlife" (p. 15), but give no designated attention to animals or human-animal relationships in their analysis. Once again, this group mentions animals or ecosystems to support the discussion of potential risks to humans.

Fourth, some articles focus on policy initiatives and debates $(n=7)$. Within this group, articles focus on policies and practices in monitoring and management (Centner and Eberhart 2015; Wylie and Albright 2014), local distance ordinances and management (Centner and Kostandini 2015; Fry 2013), political debates and public policy (Bamberger and Oswald 2013; Beebeejaun 2013), and national acts and orders (Geltman et al. 2016). As with the others, articles in this subtheme either do not specifically mention animals or only mention them to support a claim about human or environmental wellbeing. The single exception to this is Bamberger and Oswald's 2015 follow up article to their original 2012 publication, in which they deliberately discuss the impact of HVHHF on livestock, mentioning that livestock remaining in HVHHF areas recovered from reproductive distress initially seen on the onset of production, but developed long-term respiratory issues.

Finally, a small group of articles provide general overviews of the impacts of HVHHF, addressing both environmental and social concerns $(n=4)$ (see, e.g., Esterhuyse et al. 2016; Hays et al. 2015; Stephenson 2016; Wang et al. 2014). Once again, this group cites Bamberger and Oswald (2012) without mentioning animals. For instance, Stephenson (2016) notes, "concerns over additives used in hydraulic fracturing fluid mainly center on them reaching the environment from spills at the surface or in transport, from illegal dumping of wastewater, or from damage to the liners of wastewater impoundment dams" (p. 8), which is followed with the Bamberger and Oswald citation. The article does not specifically mention animals. By evaluating articles in the animal sentinel theme, two conclusions emerge. First, the majority of articles that cite the Bamberger and Oswald (2012) article only use the citation to situate research on the impacts of HVHHF on humans, paying little or no attention to the direct impacts that HVHHF has on animals and human-animal relationships. Second, it is clear that social science, including environmental justice scholars, have neglected this area of research.

\section{Conclusions}

As HVHHF continues to expand, numerous environmental and social impacts are being acknowledged; however, the place of animals in this discourse remains limited, especially among social scientists (see, e.g., Whitley 2017, 2018). Assessing the impacts of HVHHF on animals and human-animal relationships is particularly important because animals have inherent value, they contribute to ecosystem viability, and there will likely be shared impacts between humans and animals. Studies that mention animals or cite animal-related research in the context of HVHHF 
can be divided into three thematic categories: animal-focused, animal-observant, and animal sentinel articles. Animal-focused articles assess the risks of HVHHF on animal life, often on a particular species. Animal-observant articles mention impacts of HVHHF on animals, but in the context of other issues or themes. Articles in this group do not focus on animals, but impacts on animals are acknowledged. Finally, the majority of articles cite animal-focused articles to make a claim about the impacts HVHHF has on something or some community other than animals. Social science work is nearly absent from all categories. Specifically, there is no focused discussion of human-animal relationships in the face of HVHHF or of how the impacts of HVHHF on animals influence social and community dynamics. The clear gap in literature mimics the assertions that social science has neglected the natural environment and, in this case, animals as an important topic of analysis for social life. What this analysis shows is that there are many ways that social scientists can engage with broadly understanding the intersection between humans, animals and energy development, and HVHHF in particular.

While some studies acknowledge the inherent value of animals (studies in the animal-focused theme), most cite risks to animals as a means of understanding the potential risks to human health. This is perhaps unsurprising, given humans' lengthy history of using animals as intentional and unintentional sentinels in energy development and the EJ focus on human lives. For instance, scholars have often argued that the tracking and monitoring of sentinel species is an important technique to assess human health risks (McCarthy et al. 1990; Rabinowitz et al. 2009). A benefit of observing animals in HVHHF areas is that this approach does not isolate and expose animals to toxic chemicals in a laboratory (Rabinowitz et al. 2010). However, animals are only tracked and monitored when exposure to humans has occurred or is expected to occur. As a consequence, such work may negate the inherent value of animals, since tracking and monitoring is unlikely to occur when there is no concern over human health risks. Tacking may also involve the capture and tracking of animals, which could put stress on a particular animal or population. In many ways, animals observed in this form have become the new "canaries in the coal mines" as unintentional sentinels.

Importantly, animals continue to be used in laboratory settings to test energy development chemicals. So, not only are animals being tracked as unintentional sentinels in their natural environments to signal human health risks, but are also being experimented on in laboratory environments to explore the toxicity of HVHHF fluids. There is growing research that suggests that experimentation on animals is often flawed, misleading, and wasteful (see, e.g., Arluke 2010; Arluke and Michael 2007; Eisenman 2016). Because of this, many scholars and industries have called for alternatives to animal-based experimentation (see, e.g., Khilnani and Khilnani 2016; Kumar et al. 2017). Although, field observation can make isolating the effects of HVHHF difficult, motivating experiments on animals, several of the studies mentioned above have used field experimentation to document impacts effectively with minimal risk to animals. Many of the field experiments have a dual human and animal focus. This means that the researchers are interested in monitoring human risk as well as supporting biodiversity. Although there has been some work to assert that animals are sentinels in HVHHF expansion, the use of animals in laboratory experiments to document the potential effects of HVHHF toxins has not been addressed. It is unlikely that many, even within Animal Rights circles, are aware of the laboratory testing conducted on animals to gain insight into the harmful effects of HVHHF chemicals. Such information may be particularly important in aligning animal rights activists and fracktivists movements (a range of people from those who strongly oppose hydraulic fracturing to those who support extensive policy and practice reform before expansion is allowed to continue). Scholars should consider looking into the use of animals in laboratory environments to get a better understanding of how widespread this practice is across energy platforms and how this practice has increased or decreased over time.

Ultimately, this content analysis of literature highlights numerous gaps in assessing the impact HVHHF has on animals and human-animal relationships. Not only are more geographically- and species-diverse studies needed to assess vulnerability and reliance by all scientists, but social scientists 
in particular need to assess the effects HVHHF has on human-animal relationships. In particular, environmental justice scholars need to include animals and human-animal relationships in their analyses of the impacts of HVHHF. Several reports suggest that people and animals may suffer shared health problems because of HVHHF. Scholars should investigate what this shared suffering means for companion animal ownership, loss, veterinary care, self-identity, and family life as well as exploring the social and psychological implications. In addition, scholars should investigate questions such as how rescue organizations are responding to HVHHF, especially in high development areas, and how people in HVHHF areas are working to keep their animals and themselves safe. Beyond this, research suggests that boomtowns may fuel social disorder, which can lead to increases in violence. Scholars should explore how animals fit into this equation and whether there is increased violence against animals in these communities.

Across thematic categories, human health remains a dominant subtheme. Most studies, regardless of their central focus, conclude by discussing the potential or realized risks of HVHHF to human health, but not to human-animal relationships. Despite this, the reality is that the impacts of HVHHF on animals will likely go beyond shared health concerns. As with the example in the beginning, seeing companion or agriculture animals in distress can increase human stress, something that has been documented in other studies, particularly in studies assessing the impacts of companion animal death on human wellbeing. Scholars should take inventory of how individuals in heavy HVHHF areas are negotiating these relationships and if the impacts on animals are having negative impacts on human mental health.

Finally, human relationships with animals may alter how people respond to HVHHF risks (see, e.g., Whitley 2017). There is some work that has also highlighted this claim, but has not evaluated this question extensively (see, e.g., McHenry 2017; Olive and Valentine 2018). More should be done to assess how our relationships with animals inform our understanding of, and response to, HVHHF risks. Identity and value structures are known to play a role in how people think about various environmental issues (see, e.g., Dietz and Whitley 2018b) and may also be important in how people think about the intersection of energy development, humans and animals. More attention should also be placed on looking at how racially diverse communities consider these issues in order to challenge the assumption that communities of color do not care about environmental issues or animals (see, e.g., Dietz and Whitley 2018a). Further, research shows that framing HVHHF in terms of impacts on animals may be powerful in generating greater concern (see, e.g., Whitley 2017). There is a wealth of studies that document the importance of how environmental issues are framed and how animal framing, such as the iconic polar bear for climate change, can drive public perception (Whitley and Kalof 2014; Kalof et al. 2017). Ultimately, this analysis suggests that there is much work to be done to centralize animals and human-animal relationships as essential in assessing the impacts of HVHHF and that this work should be done by social scientists from an environmental justice perspective, supporting Schlosberg (2013) assertion that we need more discussions of animals as victims in environmental justice narratives.

There are limitations to this study. The focus on peer-reviewed published articles could be considered a limitation. There are several non-peer-reviewed sources that address the impacts of HVHHF on animals (DeDonder et al. 2015; Hill 2013; National Parks Conservation Association 2013). Further, there may be additional social and natural science HVHHF articles that discuss animals, but that were not considered as contributing to the dominant discussion because they did not cite the Bamberger and Oswald (2012) article and could not be found when searching for animal key terms. Finally, because of the historical exclusion of the natural environment and animals from social science literature, there may be social science scholars working in this area that have yet to publish their work. If this is the case, broad searches of all materials including conference papers, dissertations, etc., should reveal additional sources that would not have been considered for this analysis but could be evaluated in the future.

Funding: This research received no external funding. 
Conflicts of Interest: The author declares no conflict of interest.

\section{References}

Abrahams, Leslie S., W. Michael Griffin, and H. Scott Matthews. 2015. Assessment of Policies to Reduce Core Forest Fragmentation from Marcellus Shale Development in Pennsylvania. Ecological Indicators 52: 153-60. [CrossRef]

Adekola, Josephine, Moira Fischbacher-Smith, Denis Fischbacher-Smith, and Olalekan Adekola. 2016. Health Risks from Environmental Degradation in the Niger Delta, Nigeria. Environment and Planning C: Government and Policy 35: 334-54. [CrossRef]

Allred, Brady W., W. Kolby Smith, Dirac Twidwell, Julia H. Haggerty, Steven W. Running, David E. Naugle, and Samuel D. Fuhlendorf. 2015. Ecosystem Services Lost to Oil and Gas in North America. Science 348: 401-2. [CrossRef]

Arent, Douglas, Jeffrey Logan, Jordan Macknick, William Boyd, Kenneth Medlock, Francis O'Sullivan, Jae Edmonds, Leon Clarke, Hillard Huntington, Garvin Heath, and et al. 2015. A Review of Water and Greenhouse Gas Impacts of Unconventional Natural Gas Development in the United States. MRS Energy $\mathcal{E}$ Sustainability 2: E4.

Arluke, Arnold. 2010. Regarding Animals. London: Pearson Education.

Arluke, Arnold, and Mike Michael. 2007. The Sacrifice: How Scientific Experiments Transform Animals and People. West Lafayette: Purdue University Press.

Bai, Linyi, Avijit Jana, Huijun Phoebe Tham, Kim Truc Nguyen, Parijat Borah, and Yanli Zhao. 2016. Remarkable Vapochromic Behavior of Pure Organic Octahedron Embedded in Porous Frameworks. Small 12: 3302-8. [CrossRef]

Bamberger, Michelle, and Robert E. Oswald. 2012. Impacts of Gas Drilling on Human and Animal Health. New Solutions: A Journal of Environmental and Occupational Health Policy 22: 51-77. [CrossRef]

Bamberger, Michelle, and Robert E. Oswald. 2013. Science and Politics of Shale Gas Extraction. New Solutions: A Journal of Environmental and Occupational Health Policy 23: 1-12. [CrossRef]

Bamberger, Michelle, and Robert E. Oswald. 2014. Unconventional Oil and Gas Extraction and Animal Health. Environmental Science: Processes \& Impacts 16: 1860-65.

Bamberger, Michelle, and Robert E. Oswald. 2015. Long-Term Impacts of Unconventional Drilling Operations on Human and Animal Health. Journal of Environmental Science and Health, Part A 50: 447-59. [CrossRef]

Barrett, Betty Jo, Amy Fitzgerald, Amy Peirone, Rochelle Stevenson, and Chi Ho Cheung. 2018. Help-Seeking among Abused Women with Pets: Evidence from a Canadian Sample. Violence and Victims 33: 604-26. [CrossRef]

Barth, Jannette M. 2013. The Economic Impact of Shale Gas Development on State and Local Economies: Benefits, Costs, and Uncertainties. New Solutions: A Journal of Environmental and Occupational Health Policy 23: 85-101. [CrossRef] [PubMed]

Beebeejaun, Yasminah. 2013. The Politics of Fracking: A Public Policy Dilemma? Political Insight 4: 18-21. [CrossRef]

Beirne, Piers. 2009. Confronting Animal Abuse: Law, Criminology, and Human-Animal Relationships. Washington: Rowman \& Littlefield Publishers.

Blewett, Tamzin A., Alyssa M. Weinrauch, Perrine L. M. Delompré, and Greg G. Goss. 2017a. The Effect of Hydraulic Flowback and Produced Water on Gill Morphology, Oxidative Stress and Antioxidant Response in Rainbow Trout (Oncorhynchus mykiss). Scientific Reports 7: 46582. Available online: https:/ /www.nature. com/articles/srep46582 (accessed on 22 January 2018). [CrossRef]

Blewett, Tamzin A., Perrine L. M. Delompré, Yuhe He, Erik J. Folkerts, Shannon L. Flynn, Daniel S. Alessi, and Greg G. Goss. 2017b. Sublethal and Reproductive Effects of Acute and Chronic Exposure to Flowback and Produced Water from Hydraulic Fracturing on the Water Flea Daphnia Magna. Environmental Science E Technology 51: 3032-39.

Boyle, Meleah D., Devon C. Payne-Sturges, Thurka Sangaramoorthy, Sacoby Wilson, Keeve E. Nachman, Kelsey Babik, Christian C. Jenkins, Joshua Trowell, Donald K. Milton, and Amir Sapkota. 2016. Hazard Ranking Methodology for Assessing Health Impacts of Unconventional Natural Gas Development and Production: The Maryland Case Study. PLoS ONE 11: e0145368. [CrossRef] 
Brand, Adrianne B., Amber N. M. Wiewel, and Evan H. Campbell Grant. 2014. Potential Reduction in Terrestrial Salamander Ranges Associated with Marcellus Shale Development. Biological Conservation 180: $233-40$. [CrossRef]

Brittingham, Margaret C., Kelly O. Maloney, Aïda M. Farag, David D. Harper, and Zachary H. Bowen. 2014. Ecological Risks of Shale Oil and Gas Development to Wildlife, Aquatic Resources and Their Habitats. Environmental Science $\mathcal{E}$ Technology 48: 11034-47.

Brown, David, Beth Weinberger, Celia Lewis, and Heather Bonaparte. 2014. Understanding Exposure from Natural Gas Drilling Puts Current Air Standards to the Test. Reviews on Environmental Health 29: 277-92. [CrossRef]

Brown, David R., Celia Lewis, and Beth I. Weinberger. 2015. Human Exposure to Unconventional Natural Gas Development: A Public Health Demonstration of Periodic High Exposure to Chemical Mixtures in Ambient Air. Journal of Environmental Science and Health, Part A 50: 460-72. [CrossRef]

Bullard, Robert D. 1994. Environmental Justice for All: It's the Right Thing to Do. Journal of Environmental Law and Litigation 9: 281-308.

Bullard, Robert D. 2005. Quest for Environmental Justice. San Francisco: Sierra Club Books.

Bullard, Robert D., and Beverly H. Wright. 1993. Environmental Justice for All: Community Perspectives on Health and Research. Toxicology and Industrial Health 9: 821-41. [CrossRef]

Bunch, A. G., Camarie S. Perry, L. Abraham, Daniele. S. Wikoff, J. Andrew Tachovsky, J. Gregory Hixon, Jonathon. D. Urban, Mark A. Harris, and Laurie C. Haws. 2014. Evaluation of Impact of Shale Gas Operations in the Barnett Shale Region on Volatile Organic Compounds in Air and Potential Human Health Risks. Science of the Total Environment 468: 832-42. [CrossRef]

Burton, G. Allen, Niladri Basu, Brian R. Ellis, Katherine E. Kapo, Sally Entrekin, and Knute Nadelhoffer. 2014. Hydraulic 'Fracking': Are Surface Water Impacts an Ecological Concern? Environmental Toxicology and Chemistry 33: 1679-89. [CrossRef]

Callicott, J. Baird. 1999. Beyond the Land Ethic: More Essays in Environmental Philosophy. Albany: SUNY Press.

Carter, Bob, and Nickie Charles. 2018. The Animal Challenge to Sociology. European Journal of Social Theory 21: 79-97. [CrossRef]

Catton, William R., and Riley E. Dunlap. 1978. Environmental Sociology: A New Paradigm. The American Sociologist 13: 41-49.

Centner, Terence J., and Nicholas S. Eberhart. 2015. The Use of Best Management Practices to Respond to Externalities from Developing Shale Gas Resources. Journal of Environmental Planning and Management. 59: 746-68. [CrossRef]

Centner, Terence J., and Genti Kostandini. 2015. Local Governments Want Authority to Address Problems: The Case of Horizontal Drilling and Hydraulic Fracturing in the United States. Land Use Policy 49: 227-35. [CrossRef]

Choma, Becky L., Yaniv Hanoch, and Shannon Currie. 2016. Attitudes toward Hydraulic Fracturing: The Opposing Forces of Political Conservatism and Basic Knowledge about Fracking. Global Environmental Change 38: 108-17. [CrossRef]

Clough, Emily, and Derek Bell. 2016. Just Fracking: A Distributive Environmental Justice Analysis of Unconventional Gas Development in Pennsylvania, USA. Environmental Research Letters 11: 025001. [CrossRef]

Colborn, Theo, Kim Schultz, Lucille Herrick, and Carol Kwiatkowski. 2012. An Exploratory Study of Air Quality near Natural Gas Operations. Human and Ecological Risk Assessment: An International Journal 20: 86-105. [CrossRef]

Crist, Eileen. 2012. Abundant Earth and Population. In Life on the Brink: Environmentalists Confront Overpopulation. Edited by Eileen Crist and Philip Cafaro. Athens: University of Georgia, pp. 141-53.

Crowe, Jessica, Tony Silva, Ryan G. Ceresola, Amanda Buday, and Charles Leonard. 2015. Differences in Public Perceptions and Leaders' Perceptions on Hydraulic Fracturing and Shale Development. Sociological Perspectives 58: 441-63. [CrossRef]

Cudworth, Erika. 2015. Killing Animals: Sociology, Species Relations and Institutionalized Violence. The Sociological Review 63: 1-18. [CrossRef] 
DeDonder, Keith D., Ronette Gehring, Ronald E. Baynes, Lisa A. Tell, Thomas W. Vickroy, and Jim E. Riviere. 2015. Oil and Petroleum Product Exposures to Livestock. Food Animal Residue Avoidance Databank. Available online: http:/ / www.farad.org/publications/perspectives/livestock\&fracking.pdf (accessed on 1 March 2017).

Dietz, Thomas, and Cameron T. Whitley. 2018a. Inequality, Decisions, and Altruism. Sociology of Development 4: 282-303. [CrossRef]

Dietz, Thomas, and Cameron T. Whitley. 2018b. Environmentalism, Norms, and Identity. Proceedings of the National Academy of Sciences USA 115: 12334-36. [CrossRef] [PubMed]

Dokshin, Fedor A. 2016. Whose Backyard and What's at Issue? Spatial and Ideological Dynamics of Local Opposition to Fracking in New York State, 2010 to 2013. American Sociological Review 81: 921-48. [CrossRef]

Down, Adrian, Martin Armes, and Robert B. Jackson. 2013. Shale Gas Extraction in North Carolina: Research Recommendations and Public Health Implications. Environmental Health Perspectives 121: A292. [CrossRef] [PubMed]

Eisenman, Stephen F. 2016. Criticizing Animal Experimentation, at My Peril. Altex 33: 3-12. [CrossRef]

Elliott, Elise G., Adrienne S. Ettinger, Brian P. Leaderer, Michael B. Bracken, and Nicole C. Deziel. 2017. A Systematic Evaluation of Chemicals in Hydraulic-fracturing Fluids and Wastewater for Reproductive and Developmental Toxicity. Journal of Exposure Science and Environmental Epidemiology 27: 1-10. [CrossRef]

Entrekin, Sally, Anne Trainor, James Saiers, Lauren Patterson, Kelly Maloney, Joseph Fargione, Joseph Kiesecker, Sharon Baruch-Mordo, Katherine Konschnik, Hannah Wiseman, and et al. 2018. Water stress from high-volume hydraulic fracturing potentially threatens aquatic biodiversity and ecosystem services in Arkansas, United States. Environmental Technology 52: 2349-58. [CrossRef]

Ernstoff, Alexi Sara, and Brian R. Ellis. 2013. Clearing the Waters of the Fracking Debate. Michigan Journal of Sustainability 1: 109-29. [CrossRef]

Esterhuyse, Surina, Marinda Avenant, Nola Redelinghuys, Andrzej Kijko, Jan Glazewski, Lisa Plit, Marthie Kemp, Ansie Smit, A. Tascha Vos, and Richard Williamson. 2016. A Review of Biophysical and Socio-Economic Effects of Unconventional Oil and Gas extraction-Implications for South Africa. Journal of Environmental Management 184: 419-30. [CrossRef] [PubMed]

Ferrar, Kyle J., Jill Kriesky, Charles L. Christen, Lynne P. Marshall, Samantha L. Malone, Ravi K. Sharma, Drew R. Michanowicz, and Bernard D. Goldstein. 2013. Assessment and Longitudinal Analysis of Health Impacts and Stressors Perceived to Result from Unconventional Shale Gas Development in the Marcellus Shale Region. International Journal of Occupational and Environmental Health 19: 104-12. [CrossRef] [PubMed]

Field, R. A., J. Soltis, and S. Murphy. 2014. Air Quality Concerns of Unconventional Oil and Natural Gas Production. Environmental Science: Processes E Impacts 16: 954-69.

Finkel, Madelon L., and Jake Hays. 2013. The Implications of Unconventional Drilling for Natural Gas: A Global Public Health Concern. Public Health 127: 889-93. [CrossRef] [PubMed]

Finkel, Madelon L., Jake Hays, and Adam Law. 2013a. The Shale Gas Boom and the Need for Rational Policy. American Journal of Public Health 103: 1161-63. [CrossRef] [PubMed]

Finkel, Medelon L., Jane Selegean, Jake Hays, and Nitin Kondamudi. 2013b. Marcellus Shale Drilling's Impact on the Dairy Industry in Pennsylvania: A Descriptive Report. New Solutions: A Journal of Environmental and Occupational Health Policy 23: 189-201. [CrossRef] [PubMed]

Fitzgerald, Amy J. 2007. 'They Gave Me a Reason to Live': The Protective Effects of Companion Animals on the Suicidality of Abused Women. Humanity \& Society 31: 355-78.

Folkerts, Erik J., Tamzin A. Blewett, Yuhe He, and Greg G. Goss. 2017. Cardio-respirometry Disruption in Zebrafish (Danio rerio) Embryos Exposed to Hydraulic Fracturing Flowback and Produced Water. Environmental Pollution 231: 1477-87. [CrossRef]

Fry, Matthew. 2013. Urban Gas Drilling and Distance Ordinances in the Texas Barnett Shale. Energy Policy 62: 79-89. [CrossRef]

Fry, Matthew, Adam Briggle, and Jordan Kincaid. 2015. Fracking and Environmental (in) Justice in a Texas City. Ecological Economics 117: 97-107. [CrossRef]

Funk, Alexander N., and Erich K. Stabenau. 2017. Examination of the Physiological Effects of Ethylene Glycol Exposure on Muscle and Liver Tissue of the Leopard Frog, Rana pipiens. The FASEB Journal 31: 874-78.

Garvie, Kathryn H., Lana Lowe, and Karena Shaw. 2014. Shale Gas Development in Fort Nelson First Nation Territory: Potential Regional Impacts of the LNG Boom. BC Studies 184: 45. 
Geltman, Elizabeth Glass, Gunwant Gill, and Miriam Jovanovic. 2016. Impact of Executive Order 13211 on Environmental Regulation: An Empirical Study. Energy Policy 89: 302-10. [CrossRef]

Gillen, Jennifer L., and Erik Kiviat. 2012. Environmental Reviews and Case Studies: Hydraulic Fracturing Threats to Species with Restricted Geographic Ranges in the Eastern United States. Environmental Practice 14: 320-31. [CrossRef]

Godwin, Braden L., Shannon E. Albeke, Harold L. Bergman, Annika Walters, and Merav Ben-David. 2015. Density of River Otters (Lontra canadensis) in Relation to Energy Development in the Green River Basin, Wyoming. Science of The Total Environment 532: 780-90. [CrossRef] [PubMed]

Goldstein, Bernard D., and Jill Kriesky. 2012. The Public Health Implications of Unconventional Natural Gas Drilling. Proceedings of the Water Environment Federation 2012: 2050-60. [CrossRef]

Graham, Jove, Jennifer Irving, Xiaoqin Tang, Stephen Sellers, Joshua Crisp, Daniel Horwitz, Lucija Muehlenbachs, Alan Krupnick, and David Carey. 2015. Increased Traffic Accident Rates Associated with Shale Gas Drilling in Pennsylvania. Accident Analysis \& Prevention 74: 203-9.

Grant, Christopher J., Alexander B. Weimer, Nicole K. Marks, Elliott S. Perow, Jacob M. Oster, Kristen M. Brubaker, Ryan V. Trexler, Caroline M. Solomon, and Regina Lamendella. 2015. Marcellus and Mercury: Assessing Potential Impacts of Unconventional Natural Gas Extraction on Aquatic Ecosystems in Northwestern Pennsylvania. Journal of Environmental Science and Health, Part A 50: 482-500. [CrossRef]

Griswold, Eliza. 2011. Situation Normal All Fracked Up. New York Times, November 20.

Hauter, Wenonah. 2016. Frackopoly: The Battle for the Future of Energy and the Environment. New York: The New Press.

Hays, Jake, Madelon L. Finkel, Michael Depledge, Adam Law, and Seth B. C. Shonkoff. 2015. Considerations for the Development of Shale Gas in the United Kingdom. Science of The Total Environment 512: 36-42. [CrossRef]

He, Yuhe, Erik J. Folkerts, Yifeng Zhang, Jonathan W. Martin, Daniel S. Alessi, and Greg G. Goss. 2016. Effects on Biotransformation, Oxidative Stress and Endocrine Disruption in Rainbow Trout (Oncorhynchus mykiss) Exposed to Hydraulic Fracturing Flowback and Produced Water. Environmental Science E Technology 51: 940-47.

He, Yuhe, Shannon L. Flynn, Erik J. Folkerts, Yifeng Zhang, Dongliang Ruan, and Daniel S. Alessi. 2017. Chemical and Toxicological Characterizations of Hydraulic Fracturing Flowback and Produced Water. Water Research 114: 78-87. [CrossRef] [PubMed]

He, Yuhe, Chenxing Sun, Yifeng Zhang, Erik J. Folkerts, Jonathan W. Martin, and Greg G. Goss. 2018. Developmental Toxicity of the Organic Fraction from Hydraulic Fracturing Flowback and Produced Waters to Early Life Stages of Zebrafish (Danio rerio). Environmental Science \& Technology 52: 3820-30.

Hill, Elaine L. 2013. Shale Gas Development and Infant Health: Evidence from Pennsylvania. Charles H. Dyson School of Applied Economics and Management, Cornell University, Working Paper. 86-105. Available online: http:/ / www.farad.org/publications/perspectives/livestock\&fracking.pdf (accessed on 1 March 2017).

Himsworth, Chelsea G., and Melanie Rock. 2013. Pet Ownership, Other Domestic Relationships, and Satisfaction with Life among Seniors: Results from a Canadian National Survey. Anthrozoös 26: 295-305. [CrossRef]

Hula, Richard C., Melanie Bowers, Cameron T. Whitley, and William Isaac. 2017. Science, Politics and Policy: How Michiganders think about the Risks Facing the Great Lakes. Human Ecology 45: 833-44. [CrossRef]

Irvine, Leslie. 2009. Filling the Ark: Animal Welfare in Disasters. Philadelphia: Temple University Press.

Israel, Andrei L., Gabrielle Wong-Parodi, Thomas Webler, and Paul C. Stern. 2015. Eliciting Public Concerns about an Emerging Energy Technology: The Case of Unconventional Shale Gas Development in the United States. Energy Research \& Social Science 8: 139-50.

Jerolmack, Colin, and Nina Berman. 2016. Fracking Communities. Public Culture 28: 193-214. [CrossRef]

Johnston, Jill E., Emily Werder, and Daniel Sebastian. 2016. Wastewater Disposal Wells, Fracking, and Environmental Injustice in Southern Texas. Journal Information 106: 550-56. [CrossRef] [PubMed]

Jones, Nathan F., Liba Pejchar, and Joseph M. Kiesecker. 2015. The Energy Footprint: How Oil, Natural Gas, and Wind Energy Affect Land for Biodiversity and the Flow of Ecosystem Services. BioScience 65: 290-301. [CrossRef]

Kalof, Linda, Cameron T. Whitley, Stephen Vrla, and Jessica Bell Rizzo. 2017. Anthropogenic Food Sources in the Co-Existence of Humans with Liminal Animals in Northern Environments. In Shared Lives of Humans and Animals: Animal Agency in the Global North. Edited by Tuomas Rasanen and Taina Syrjamma. New York: Routledge, pp. 147-62. 
Kassotis, Christopher D., Donald E. Tillitt, J. Wade Davis, Annette M. Hormann, and Susan C. Nagel. 2013. Estrogen and Androgen Receptor Activities of Hydraulic Fracturing Chemicals and Surface and Ground Water in a Drilling-Dense Region. Endocrinology 155: 897-907. [CrossRef] [PubMed]

Kassotis, Christopher D., Kara C. Klemp, Danh C. Vu, Chung-Ho Lin, Chun-Xia Meng, Cynthia L. Besch-Williford, Lisa Pinatti, R. Thomas Zoeller, Erma Z. Drobnis, Victoria D. Balise, and et al. 2015. Endocrine-Disrupting Activity of Hydraulic Fracturing Chemicals and Adverse Health Outcomes after Prenatal Exposure in Male Mice. Endocrinology 156: 4458-73. [CrossRef]

Kassotis, Christopher D., John J. Bromfield, Kara C. Klemp, Chun-Xia Meng, Andrew Wolfe, R. Thomas Zoeller, Victoria D. Balise, Chiamaka J. Isiguzo, Donald E. Tillitt, and Susan C. Nagel. 2016a. Adverse Reproductive and Developmental Health Outcomes Following Prenatal Exposure to a Hydraulic Fracturing Chemical Mixture in Female C57Bl/6 Mice. Endocrinology 157: 3469-81. [CrossRef] [PubMed]

Kassotis, Christopher D., Luke R. Iwanowicz, Denise M. Akob, Isabelle M. Cozzarelli, Adam C. Mumford, William H. Orem, and Susan C. Nagel. 2016b. Endocrine Disrupting Activities of Surface Water Associated with a West Virginia Oil and Gas Industry Wastewater Disposal Site. Science of The Total Environment 557: 901-10. [CrossRef] [PubMed]

Khilnani, Gurudas, and Ajeet Kumar Khilnani. 2016. Restructuring Postgraduate Curriculum in Pharmacology: Time to Incorporate Alternatives to Animal Experimentation. Indian Journal of Pharmacology 48: 336. [CrossRef] [PubMed]

Kiviat, Erik. 2013. Risks to Biodiversity from Hydraulic Fracturing for Natural Gas in the Marcellus and Utica Shales. Annals of the New York Academy of Sciences 1286: 1-14. [CrossRef] [PubMed]

Koh, Amanda, Anna Wong, Alexis Quinteros, Christine Desplat, and Richard Gross. 2016. Influence of Sophorolipid Structure on Interfacial Properties of Aqueous-Arabian Light Crude and Related Constituent Emulsions. Journal of the American Oil Chemists' Society 94: 1-13. [CrossRef]

Konkel, Lindsey. 2016. Salting the Earth: The Environmental Impact of Oil and Gas Wastewater Spills. Environmental Health Perspectives 124: A230. [CrossRef] [PubMed]

Kopnina, Helen. 2012a. Re-Examining Culture/Conservation Conflict: The View of Anthropology of Conservation through the Lens of Environmental Ethics. Journal of Integrative Environmental Sciences 9: 9-25. [CrossRef]

Kopnina, Helen. 2012b. Toward Conservational Anthropology: Addressing Anthropocentric Bias in Anthropology. Dialectical Anthropology 36: 127-46. [CrossRef]

Kopnina, Helen. 2014. Environmental Justice and Biospheric Egalitarianism: Reflecting on a Normative-Philosophical View of Human-Nature Relationship. Earth Perspectives 1: 8. [CrossRef]

Korfmacher, Katrina Smith, Walter A. Jones, Samantha L. Malone, and Leon F. Vinci. 2013. Public Health and High Volume Hydraulic Fracturing. New Solutions: A Journal of Environmental and Occupational Health Policy 23: 13-31. [CrossRef]

Kovats, Sari, Michael Depledge, Andy Haines, Lora E. Fleming, Paul Wilkinson, Seth B. Shonkoff, and Noah Scovronick. 2014. The Health Implications of Fracking. The Lancet 383: 757. [CrossRef]

Kumar, Vipin, Avantika Chandra, and Zeba Usmani. 2017. Impact of Coal Mining on Soil Properties and Their Efficient Eco-Restoration. International Journal of Energy Technology and Policy 13: 158-65. [CrossRef]

Kun, Luis, B. Linkous, C. Gibson, and N. Roldos. 2014. The Arsenic Threat: Interdependencies of Water, Agriculture, Food Supply, Public Health and Energy Critical Infrastructure. Health and Technology 4: 145-57. [CrossRef]

Ladd, Anthony E. 2013. Stakeholder Perceptions of Socioenvironmental Impacts from Unconventional Natural Gas Development and Hydraulic Fracturing in the Haynesville Shale. Journal of Rural Social Sciences 28: 56.

Ladd, Anthony E. 2018. Fractured Communities: Risk, Impacts, and Protest Against Hydraulic Fracking in US Shale Regions. New Brunswick: Rutgers University Press.

Latta, Steven C., Leesia C. Marshall, Mack W. Frantz, and Judith D. Toms. 2015. Evidence from Two Shale Regions That a Riparian Songbird Accumulates Metals Associated with Hydraulic Fracturing. Ecosphere 6: 1-10. [CrossRef]

Lave, Rebecca, and Brian Lutz. 2014. Hydraulic Fracturing: A Critical Physical Geography Review. Geography Compass 8: 739-54. [CrossRef]

Lendrum, Patrick E., Charles R. Anderson Jr., Ryan A. Long, John G. Kie, and R. Terry Bowyer. 2012. Habitat Selection by Mule Deer during Migration: Effects of Landscape Structure and Natural-Gas Development. Ecosphere 3: 82. [CrossRef] 
Lloyd, Penn, Thomas E. Martin, Roland L. Redmond, Ute Langner, and Melissa M. Hart. 2005. Linking Demographic Effects of Habitat Fragmentation across Landscapes to Continental Source-sink Dynamics. Ecological Applications 15: 1504-14. [CrossRef]

Loh, Hsue-Peng, and Nancy Loh. 2016. Hydraulic Fracturing and Shale Gas: Environmental and Health Impacts. In Advances in Water Resources Management. Berlin: Springer, pp. 293-337.

Lutz, Allison K., and Christopher J. Grant. 2016. Impacts of Hydraulic Fracturing Development on Macroinvertebrate Biodiversity and Gill Morphology of Net-Spinning Caddisfly (Hydropsychidae, Diplectrona) in Northwestern Pennsylvania, USA. Journal of Freshwater Ecology 31: 211-17. [CrossRef]

Ma, Zhen-qianq, Katie C. Sneeringer, Longjian Liu, and Lewis H. Kuller. 2016. Time Series Evaluation of Birth Defects in Areas with and without Unconventional Natural Gas Development. Journal of Epidemiol Public Health Rev 1: 1-7. [CrossRef]

Massari, Monica, and Paola Monzini. 2004. Dirty Businesses in Italy: A Case-Study of Illegal Trafficking in Hazardous Waste. Global Crime 6: 285-304. [CrossRef]

McCarthy, John F., Braulio D. Jimenez, Lee R. Shugart, Frederick V. Sloop, and Aimo Oikari. 1990. Biological Markers in Animal Sentinels: Laboratory Studies Improve Interpretation of Field Data. In In Situ Evaluation of Biological Hazards of Environmental Pollutants. Berlin: Springer, pp. 163-75.

McHenry, Kristen Abatsis. 2017. Fracking Women: A Feminist Critical Analysis of Hydraulic Fracturing in Pennsylvania. IJFAB: International Journal of Feminist Approaches to Bioethics 10: 79-104. [CrossRef]

Mitka, Mike. 2012. Rigorous Evidence Slim for Determining Health Risks from Natural Gas Fracking. Journal of the American Medical Association 307: 2135-36. [CrossRef] [PubMed]

Mohai, Paul, and Robin Saha. 2006. Reassessing Racial and Socioeconomic Disparities in Environmental Justice Research. Demography 43: 383-99. [CrossRef] [PubMed]

Mohai, Paul, and Robin Saha. 2007. Racial Inequality in the Distribution of Hazardous Waste: A National-level Reassessment. Social Problems 54: 343-70. [CrossRef]

Mohai, Paul, David Pellow, and J. Timmons Roberts. 2009. Environmental Justice. Annual Review of Environment and Resources 34: 405-30. [CrossRef]

Moore, Christopher W., Barbara Zielinska, Gabrielle Pétron, and Robert B. Jackson. 2014. Air Impacts of Increased Natural Gas Acquisition, Processing, and Use: A Critical Review. Environmental Science E Technology 48: 8349-59.

Moran, Matthew D., A. Brandon Cox, Rachel L. Wells, Chloe C. Benichou, and Maureen R. McClung. 2015. Habitat Loss and Modification due to Gas Development in the Fayetteville Shale. Environmental Management 55: 1276-84. [CrossRef] [PubMed]

Morrone, Michele, Amy E. Chadwick, and Natalie Kruse. 2015. A Community Divided: Hydraulic Fracturing in Rural Appalachia. Journal of Appalachian Studies 21: 207-28. [CrossRef]

Muresan, Jianu Daniel, and Mihail Vincentiu Ivan. 2015. Controversies Regarding Costs, Uncertainties and Benefits Specific to Shale Gas Development. Sustainability 7: 2473-89. [CrossRef]

National Parks Conservation Association. 2013. National Parks and Hydraulic Fracturing: Balancing Energy Needs, Nature, and America's National Heritage. Washington: NPCA Center for Park Research, Available online: https: / / www.npca.org/resources/2663-national-parks-and-hydraulic-fracturing (accessed on 13 February 2019).

Nibert, David. 2002. Animal Rights/Human Rights: Entanglements of Oppression and Liberation. Washington: Rowman \& Littlefield Publishers.

Olive, Andrea, and Katie Valentine. 2018. Is Anyone Out There? Exploring Saskatchewan's Civil Society Involvement in Hydraulic Fracturing. Energy Research \& Social Science 39: 192-97.

Papoulias, Diana M., and Anthony L. Velasco. 2013. Histopathological Analysis of Fish from Acorn Fork Creek, Kentucky, Exposed to Hydraulic Fracturing Fluid Releases. Southeastern Naturalist 12: 92-111.

Payne, Madeleine E., Heather F. Chapman, Janet Cumming, and Frederic D. L. Leusch. 2014. In Vitro Cytotoxicity Assessment of a Hydraulic Fracturing Fluid. Environmental Chemistry 12: 286-92. [CrossRef]

Pearce, Frank, and Steve Tombs. 2009. Toxic Capitalism: Corporate Crime and the Chemical Industry. London: Open University Press.

Peggs, Kay. 2012. Animals and Sociology. Berlin: Springer.

Pellow, David Naguib. 2014. Total Liberation: The Power and Promise of Animal Rights and the Radical Earth Movement. Minneapolis: University of Minnesota Press.

Pellow, David Naguib. 2017. What Is Critical Environmental Justice? Medford: Polity Press. 
Penning, Trevor M., Patrick N. Breysse, Kathleen Gray, Marilyn Howarth, and Beizhan Yan. 2014. Environmental Health Research Recommendations from the Inter-Environmental Health Sciences Core Center Working Group on Unconventional Natural Gas Drilling Operations. Environmental Health Perspectives 122: 1155. [CrossRef] [PubMed]

Penningroth, Stephen M., Matthew M. Yarrow, Abner X. Figueroa, Rebecca J. Bowen, and Soraya Delgado. 2013. Community-Based Risk Assessment of Water Contamination from High-Volume Horizontal Hydraulic Fracturing. New Solutions: A Journal of Environmental and Occupational Health Policy 23: 137-66. [CrossRef] [PubMed]

Perry, Simona L. 2012. Environmental Reviews and Case Studies: Addressing the Societal Costs of Unconventional Oil and Gas Exploration and Production: A Framework for Evaluating Short-Term, Future, and Cumulative Risks and Uncertainties of Hydrofracking. Environmental Practice 14: 352-65. [CrossRef]

Perry, Simona L. 2013. Using Ethnography to Monitor the Community Health Implications of Onshore Unconventional Oil and Gas Developments: Examples from Pennsylvania's Marcellus Shale. New Solutions: A Journal of Environmental and Occupational Health Policy 23: 33-53. [CrossRef]

Phillips, Susan. 2012. Dead Calves and Hairless Puppies. State Impact NPR, January 19. Available online: https:/ / stateimpact.npr.org/pennsylvania/2012/01/19/dead-calves-and-hairless-puppies/ (accessed on 20 August 2015).

Pothukuchi, Kameshwari, Melissa Arrowsmith, and Natalie Lyon. 2018. Hydraulic Fracturing: A Review of Implications for Food Systems Planning. Journal of Planning Literature 33: 155-70. [CrossRef]

Powers, Martha, Poune Saberi, Richard Pepino, Emily Strupp, Eva Bugos, and Carolyn C. Cannuscio. 2015. Popular Epidemiology and 'fracking': Citizens' Concerns Regarding the Economic, Environmental, Health and Social Impacts of Unconventional Natural Gas Drilling Operations. Journal of Community Health 40: 534-41. [CrossRef]

Rabinowitz, Peter, Matthew Scotch, and Lisa Conti. 2009. Human and Animal Sentinels for Shared Health Risks. Veterinaria Italiana 45: 23.

Rabinowitz, Peter M., Matthew L. Scotch, and Lisa A. Conti. 2010. Animals as Sentinels: Using Comparative Medicine to Move beyond the Laboratory. ILAR Journal 51: 262-67. [CrossRef]

Rabinowitz, Peter M., Ilya B. Slizovskiy, Vanessa Lamers, Sally J. Trufan, Theodore R. Holford, James D. Dziura, Peter N. Peduzzi, Michael J. Kane, John S. Reif, Theresa R. Weiss, and et al. 2015. Proximity to Natural Gas Wells and Reported Health Status: Results of a Household Survey in Washington County, Pennsylvania. Environmental Health Perspectives 123: 21. [CrossRef] [PubMed]

Rafferty, Margaret A., and Elena Limonik. 2013. Is Shale Gas Drilling an Energy Solution or Public Health Crisis? Public Health Nursing 30: 454-62. [CrossRef] [PubMed]

Ralston, Jonah J., and Jason A. Kalmbach. 2018. Regulating Under Conditions of Uncertainty and Risk: Lessons learned from state regulation of hydraulic fracturing. Environmental Practice 20: 68-79. [CrossRef]

Redmond, Helen. 2014. Impact of Energy Generation on Health: Unconventional Gas. Proceedings of the Royal Society of Victoria 126: 38-39. [CrossRef]

Reible, Danny D., Soraya Honarparvar, Chau-Chyun Chen, Tissa H. Illangasekare, and Margaret MacDonell. 2016. Environmental Impacts of Hydraulic Fracturing. In Environmental Technology in the Oil Industry. Berlin: Springer, pp. 199-219.

Rich, Alisa L., and Ernest C. Crosby. 2013. Analysis of Reserve Pit Sludge from Unconventional Natural Gas Hydraulic Fracturing and Drilling Operations for the Presence of Technologically Enhanced Naturally Occurring Radioactive Material (TENORM). New Solutions: A Journal of Environmental and Occupational Health Policy 23: 117-35. [CrossRef] [PubMed]

Robbins, Kalyani. 2013. Awakening the Slumbering Giant: How Horizontal Drilling Technology Brought the Endangered Species Act to Bear on Hydraulic Fracturing. Case Western Reserve Law Review 63: 13-16.

Ruddell, Rick, and Natalie R. Ortiz. 2014. Boomtown Blues: Long-Term Community Perceptions of Crime and Disorder. American Journal of Criminal Justice 40: 129-46. [CrossRef]

Ruggiero, Vincenzo. 1996. Organized and Corporate Crime in Europe: Offers That Can't Be Refused. Hanover: Dartmouth.

Saberi, Pouné. 2013. Navigating Medical Issues in Shale Territory. New Solutions: A Journal of Environmental and Occupational Health Policy 23: 209-21. [CrossRef] 
Saberi, Pouné, Kathleen Joy Propert, Martha Powers, Edward Emmett, and Judith Green-McKenzie. 2014. Field Survey of Health Perception and Complaints of Pennsylvania Residents in the Marcellus Shale Region. International Journal of Environmental Research and Public Health 11: 6517-27. [CrossRef]

Sang, Wenjing, Cathelijne R. Stoof, Wei Zhang, Verónica L. Morales, Bin Gao, Robert W. Kay, Lin Liu, Yalei Zhang, and Tammo S. Steenhuis. 2014. Effect of Hydrofracking Fluid on Colloid Transport in the Unsaturated Zone. Environmental Science \& Technology 48: 8266-74.

Saunders, P. J., D. McCoy, R. Goldstein, A. T. Saunders, and A. Munroe. 2016. A Review of the Public Health Impacts of Unconventional Natural Gas Development. Environmental Geochemistry and Health 40: 1-57. [CrossRef] [PubMed]

Schlosberg, David. 2013. Theorising Environmental Justice: The Expanding Sphere of a Discourse. Environmental Politics 22: 37-55. [CrossRef]

Shonkoff, Seth B. C., Jake Hays, and Madelon L. Finkel. 2014. Environmental Public Health Dimensions of Shale and Tight Gas Development. Environmental Health Perspectives 122: 787-95. [CrossRef]

Short, Damien, Jessica Elliot, Kadin Norder, Edward Lloyd-Davies, and Joanna Morley. 2015. Extreme Energy, 'fracking' and Human Rights: A New Field for Human Rights Impact Assessments? The International Journal of Human Rights 19: 697-736. [CrossRef]

Slizovskiy, Ilya B., Lisa A. Conti, Sally J. Trufan, John S. Reif, Vanessa T. Lamers, Meredith H. Stowe, J. Dziura, and Peter M. Rabinowitz. 2015. Reported Health Conditions in Animals Residing near Natural Gas Wells in Southwestern Pennsylvania. Journal of Environmental Science and Health, Part A 50: 473-81. [CrossRef] [PubMed]

Souther, Sara, Morgan W. Tingley, Viorel D. Popescu, David TS Hayman, Maureen E. Ryan, Tabitha A. Graves, Brett Hartl, and Kimberly Terrell. 2014. Biotic Impacts of Energy Development from Shale: Research Priorities and Knowledge Gaps. Frontiers in Ecology and the Environment 12: 330-38. [CrossRef]

Stearman, Loren W., Ginny Adams, and Reid Adams. 2015. Ecology of the Redfin Darter and a Potential Emerging Threat to Its Habitat. Environmental Biology of Fishes 98: 623-35. [CrossRef]

Steinzor, Nadia, Wilma Subra, and Lisa Sumi. 2013. Investigating Links between Shale Gas Development and Health Impacts through a Community Survey Project in Pennsylvania. New Solutions: A Journal of Environmental and Occupational Health Policy 23: 55-83. [CrossRef]

Stephenson, Michael H. 2016. Shale Gas in North America and Europe. Energy Science E Engineering 4: 4-13.

Taylor, Dorceta E. 2000. The Rise of the Environmental Justice Paradigm: Injustice Framing and the Social Construction of Environmental Discourses. American Behavioral Scientist 43: 508-80. [CrossRef]

Thompson, Sarah J., Douglas H. Johnson, Neal D. Niemuth, and Christine A. Ribic. 2015. Avoidance of Unconventional Oil Wells and Roads Exacerbates Habitat Loss for Grassland Birds in the North American Great Plains. Biological Conservation 192: 82-90. [CrossRef]

Ticleanu, M., Radu Nicolescu, and Adriana Ion. 2014. Exploitation of Shale Gas by Hydraulic Fracturing-A Method with Possible Middle and Long Term Catastrophic Consequenses. Paper presented at the 14th SGEM GeoConference on Ecology, Economics, Education and Legislation Albena, Bulgeria, June 19-25; pp. 299-306.

Tovey, Hilary. 2003. Theorising Nature and Society in Sociology: The Invisibility of Animals. Sociologia Ruralis 43: 196-215. [CrossRef]

Tuller, David. 2015. As Fracking Booms, Dearth of Health Risk Data Remains. Health Affairs 34: 903. [CrossRef] [PubMed]

Vandecasteele, Ine, Inés Marí Rivero, Serenella Sala, Claudia Baranzelli, Ricardo Barranco, Okke Batelaan, and Carlo Lavalle. 2015. Impact of Shale Gas Development on Water Resources: A Case Study in Northern Poland. Environmental Management 55: 1285-99. [CrossRef]

Vasi, Ion Bogdan, Edward T. Walker, John S. Johnson, and Hui Fen Tan. 2015. 'No Fracking Way!' Documentary Film, Discursive Opportunity, and Local Opposition against Hydraulic Fracturing in the United States, 2010 to 2013. American Sociological Review 80: 934-59. [CrossRef]

Wang, Qiang, Xi Chen, Awadhesh N. Jha, and Howard Rogers. 2014. Natural Gas from Shale Formation-The Evolution, Evidences and Challenges of Shale Gas Revolution in United States. Renewable and Sustainable Energy Reviews 30: 1-28. [CrossRef] 
Wattenberg, Elizabeth V., Jeffrey M. Bielicki, Ashley E. Suchomel, Jessica T. Sweet, Elizabeth M. Vold, and Gurumurthy Ramachandran. 2015. Assessment of the Acute and Chronic Health Hazards of Hydraulic Fracturing Fluids. Journal of Occupational and Environmental Hygiene 12: 611-24. [CrossRef]

Webb, Ellen, Sheila Bushkin-Bedient, Amanda Cheng, Christopher D. Kassotis, Victoria Balise, and Susan C. Nagel. 2014. Developmental and Reproductive Effects of Chemicals Associated with Unconventional Oil and Natural Gas Operations. Reviews on Environmental Health 29: 307-18. [CrossRef]

Weltman-Fahs, Maya, and Jason M. Taylor. 2013. Hydraulic Fracturing and Brook Trout Habitat in the Marcellus Shale Region: Potential Impacts and Research Needs. Fisheries 38: 4-15. [CrossRef]

Werner, Angela K., Sue Vink, Kerrianne Watt, and Paul Jagals. 2015. Environmental Health Impacts of Unconventional Natural Gas Development: A Review of the Current Strength of Evidence. Science of the Total Environment 505: 1127-41. [CrossRef] [PubMed]

White, Rob. 2013. Resource Extraction Leaves Something behind: Environmental Justice and Mining. International Journal for Crime, Justice and Social Democracy 2: 50-64. [CrossRef]

Whitley, Cameron T. 2017. Altruism, Risk, Energy Development and the Human-Animal Relationship. East Lansing: Michigan State University.

Whitley, Cameron T. 2018. Engines, Sentinels, and Objects: Assessing the Impacts of Unconventional Energy Development on Animals in the Marcellus Shale Region. In Fractured Communities: Risk, Impacts, and Protest Against Hydraulic Fracturing in US Shale Regions. Edited by Anthony E. Ladd. New Brunswick: Rutgers University Press, pp. 128-48.

Whitley, Cameron T., and Linda Kalof. 2014. Animal Imagery in the Discourse of Climate Change. International Journal of Sociology 44: 10-33. [CrossRef]

Willems, Mieke, Mohamed Aqiel Dalvie, Leslie London, and Hanna-Andrea Rother. 2016. Environmental Reviews and Case Studies: Health Risk Perception Related to Fracking in the Karoo, South Africa. Environmental Practice 18: 53-68. [CrossRef]

Willits, Fern K., Gene L. Theodori, and A. E. Luloff. 2016. Self-Reported Familiarity of Hydraulic Fracturing and Support for Natural Gas Drilling: Substantive and Methodological Considerations. Journal of Rural Social Sciences 31: 83-101.

Wylie, Sara, and Len Albright. 2014. WellWatch: Reflections on Designing Digital Media for Multi-Sited Para-Ethnography. Journal of Political Ecology 21: 321-48. [CrossRef]

Yao, Yixin, Tingting Chen, Steven S. Shen, Yingmei Niu, Thomas L. DesMarais, Reka Linn, Eric Saunders, Zhihua Fan, Paul Lioy, Thomas Kluz, and et al. 2015. Malignant Human Cell Transformation of Marcellus Shale Gas Drilling Flow Back Water. Toxicology and Applied Pharmacology 288: 121-30. [CrossRef]

Zhai, Jun, Zejin Huang, Md Hasibur Rahaman, Yue Li, Longyue Mei, Hongpu Ma, Xuebin Hu, Haiwen Xiao, Zhiyong Luo, and Kunping Wang. 2016. Comparison of Coagulation Pretreatment of Produced Water from Natural Gas Well by Polyaluminium Chloride and Polyferric Sulphate Coagulants. Environmental Technology 38: 1200-10. [CrossRef]

(C) 2019 by the author. Licensee MDPI, Basel, Switzerland. This article is an open access article distributed under the terms and conditions of the Creative Commons Attribution (CC BY) license (http:// creativecommons.org/licenses/by/4.0/). 